\title{
Anticancer potential of Thevetia peruviana fruit methanolic extract
}

\author{
Alberto Ramos-Silva ${ }^{1 \dagger}$, Faviola Tavares-Carreón ${ }^{1 \dagger}$, Mario Figueroa ${ }^{2}$, Susana De la Torre-Zavala ${ }^{1}$, \\ Argel Gastelum-Arellanez ${ }^{1}$, Aída Rodríguez-García ${ }^{1}$, Luis J. Galán-Wong ${ }^{1}$ and Hamlet Avilés-Arnaut ${ }^{*}$
}

\begin{abstract}
Background: Thevetia peruviana (Pers.) K. Schum or Cascabela peruviana (L.) Lippold (commonly known as ayoyote, codo de fraile, lucky nut, or yellow oleander), native to Mexico and Central America, is a medicinal plant used traditionally to cure diseases like ulcers, scabies, hemorrhoids and dissolve tumors. The purpose of this study was to evaluate the cytotoxic, antiproliferative and apoptotic activity of methanolic extract of T. peruviana fruits on human cancer cell lines.
\end{abstract}

Methods: The cytotoxic activity of T. peruviana methanolic extract was carried out on human breast, colorectal, prostate and lung cancer cell lines and non-tumorigenic control cells (fibroblast and Vero), using the MTT assay. For proliferation and motility, clonogenic and wound-healing assays were performed. Morphological alterations were monitored by trypan blue exclusion, as well as DNA fragmentation and AO/EB double staining was performed to evaluate apoptosis. The extract was separated using flash chromatography, and the resulting fractions were evaluated on colorectal cancer cells for their cytotoxic activity. The active fractions were further analyzed through mass spectrometry.

Results: The T. peruviana methanolic extract exhibited cytotoxic activity on four human cancer cell lines: prostate, breast, colorectal and lung, with values of $\mathrm{IC}_{50} 1.91 \pm 0.76,5.78 \pm 2.12,6.30 \pm 4.45$ and $12.04 \pm 3.43 \mu \mathrm{g} / \mathrm{mL}$, respectively. The extract caused a significant reduction of cell motility and colony formation on all evaluated cancer cell lines. In addition, morphological examination displayed cell size reduction, membrane blebbing and detachment of cells, compared to non-treated cancer cell lines. The T. peruviana extract induced apoptotic cell death, which was confirmed by DNA fragmentation and AO/EB double staining. Fractions 4 and 5 showed the most effective cytotoxic activity and their MS analysis revealed the presence of the secondary metabolites: thevetiaflavone and cardiac glycosides.

Conclusion: T. peruviana extract has potential as natural anti-cancer product with critical effects in the proliferation, motility, and adhesion of human breast and colorectal cancer cells, and apoptosis induction in human prostate and lung cancer cell lines, with minimal effects on non-tumorigenic cell lines.

Keywords: Cytotoxic activity, Anti-proliferative activity, Motility, Apoptosis, Human cancer cells, Flavonoid, Cardiac glycosides

\section{Background}

Cancer is one of the most important causes of death worldwide. In 2012, 8.2 million cancer-related deaths were reported and the number of new cases is expected to rise by about $70 \%$ over the next two decades [1]. Cancer is characterized by the uncontrolled and invasive

\footnotetext{
* Correspondence: hamlet.avilesarn@uanl.edu.mx

${ }^{\dagger}$ Equal contributors

'Instituto de Biotecnología, Facultad de Ciencias Biológicas, Universidad Autónoma de Nuevo León, Avenida Universidad S/N, Ciudad Universitaria, CP 66455 San Nicolás de los Garza, NL, Mexico

Full list of author information is available at the end of the article
}

growth of cells. The most peculiar feature of cancer cells is their ability to metastasize to other specific organs. For example, prostate and colon cancer metastasize to bones and liver, respectively; lung cancer cells spread to adrenal glands, liver, brain, and bones, while breast cancer cells metastasize to lungs and bones [2]. For the most important adenocarcinomas, such as lung, breast, or colorectal cancer, the treatment is barely effective, due to metastatic disease responding only transiently to conventional treatments [3]. Therefore, scientists are still utilizing 
new alternatives in attempts to find novel compounds and strategies for the treatment of this disease [4].

Plants are a valuable source of new biologically active molecules due to the presence of hundreds of biologically active components [5]. One of the plant families i.e., Apocynaceae, is well-known for anticancer activities, mainly in the genera of Catharanthus, Nerium, Strophanthus, Apocynum and Thevetia [6]. Thevetia peruviana (Pers.) K. Schum, also known as Cascabela peruviana (L.) Lippold, yellow oleander or lucky nut in the West Indies, shows a diverse array of properties ranging from being a cardiotonic to a toxin. T. peruviana plant has been used traditionally for the treatment of gastrointestinal and inflammatory diseases, heart failures and skin tumors $[7,8]$. All parts of the plant are poisonous due to the presence of cardiac toxins, but the fruit of $T$. peruviana, is the most toxic part of the plant because it has the highest and diverse content of cardiac glycosides. There are many known cases of intentional and accidental poisoning of humans through ingestion of fruits and leaves [9]. Whereas about 10 fruits consumed may be fatal for an adult, a single fruit may be lethal for a child. The common clinical set of symptoms resembles digitalis poisoning with marked nausea, vomiting, abdominal pain, diarrhea, dysrhythmias, and hyperkalemia [10]. Although the anticancer potential of parts of T. peruviana plant, such as leaves, bark and seeds has been evaluated against human gastric and pancreatic cancer cell lines [11], the anticancer potential of T. peruviana fruit is still unknown because only a few cardiac glycosides have been identified and examined as cytotoxic agents. Therefore, the T. peruviana fruit extract has been investigated in this study to explore its anticancer potential against the most common cancer types (lung, breast, prostate and colorectal), in terms of morphological analysis, motility and cell adhesive properties, DNA damage and induction of apoptosis in human cancer cell lines.

\section{Methods}

A $T$. peruviana plant specimen was collected in San Nicolás de los Garza, N.L., México $\left(25^{\circ} 43^{\prime} 59.57^{\prime \prime} \mathrm{N}, 100^{\circ}\right.$ $\left.16^{\prime} 4.75^{\prime \prime} \mathrm{W}\right)$. Botanical authentication of the material was performed by the Botany Department Staff of Facultad de Ciencias Biológicas, UANL. A specimen of T. peruviana was recently deposited in the Herbarium of the Facultad de Ciencias Biológicas, Universidad Autónoma de Nuevo León (voucher UNL-028732).

\section{Extraction and preparation of plant samples for testing}

The plant extracts were obtained from samples $(20 \mathrm{~g})$ of dried roots, leaves, or aerial parts through maceration with methanol $(3 \times 300 \mathrm{~mL})$ at room temperature for $24 \mathrm{~h}$ and under continuous shaking. The methanolic extracts were filtered and evaporated under reduced pressure using a rotary evaporator (Yamato RE801). Samples were stored at $-20{ }^{\circ} \mathrm{C}$ prior to further experiments. For the cytotoxicity assays, the dried methanol extract was dissolved in dimethylsulfoxide (DMSO) in order to obtain a final concentration of $100 \mathrm{mg} / \mathrm{mL}$ (stock) and diluted in PBS (phosphate buffer saline). DMSO concentration in the culture medium was less than $0.1 \%$. Doxorubicin $(10 \mu \mathrm{g} / \mathrm{mL}$, Zytokil) treated cells and untreated cells were used as positive control and negative control, respectively. The methanolic extract of $T$. peruviana was fractionated by column chromatography. Briefly, $1.5 \mathrm{~g}$ of fruit extract was adsorbed onto Celite 545 and subjected to reverse flash chromatography on a 50 g RediSep Rf Gold HP $\mathrm{C}_{18}$ column, eluting with 10:90 $\mathrm{MeOH}-\mathrm{H}_{2} \mathrm{O}$ for $4 \mathrm{CV}$. Then a linear gradient from 10:90 MeOH- $\mathrm{H}_{2} \mathrm{O}$ to $100 \% \mathrm{MeOH}$ for $25 \mathrm{CV}$, holding $100 \% \mathrm{MeOH}$ for $8 \mathrm{CV}$, at a flow rate of $40 \mathrm{~mL} / \mathrm{min}$ to give 120 fractions each containing $12 \mathrm{~mL}$. The resulting fractions were then pooled according to their ELSD and UV profiles, which resulted in six combined fractions in total. All fractions were examined by UPLC-PDA-HRMS-MS/MS and tested for cytotoxic activity against human prostate carcinoma cell line (HTB-81) by the MTT colorimetric assay.

\section{Cell lines and cell culture}

The cancer cell lines used in this study were human colorectal adenocarcinoma (HTB-38), lung carcinoma (HTB-177), prostate adenocarcinoma (HTB-81), and breast adenocarcinoma (HTB-22), whereas the normal cell lines used were human skin fibroblast (CCL-116) and Vero cell line (CCL-81). Cell lines were obtained from the American Type Culture Collection (ATCC). Cell lines were cultured in DMEM or RPMI (only for HTB-81) supplemented with $10 \%(v / v)$ fetal bovine serum (Byproductos). All cells were cultured at $37^{\circ} \mathrm{C}$ under a humidified atmosphere containing $5 \% \mathrm{CO}_{2}$.

\section{Cytotoxicity assay}

For the cytotoxicity assay, $5 \times 10^{4-} 6 \times 10^{4}$ cells for colorectal, lung, breast, prostate cancer cells, and normal cells were seeded in 96-well tissue culture plates. When the cells had reached $75 \%$ confluence, they were incubated using the methanol extracts at various concentrations. After $24 \mathrm{~h}$ of incubation, the cytotoxicity was assessed using the MTT assay as described previously [12]. To obtain the half maximal inhibitory concentration $\left(\mathrm{IC}_{50}\right)$, the percentages of cell viability and growth inhibition were calculated according to the following equations [13]. Cell viability $(\%)=[(\mathrm{OD}$ of treated cells-OD of blank)/ (OD of control-OD of blank)] $\times 100$. Growth inhibition $(\%)=100-$ Cell viability (\%). All determinations were performed five times independently with three technical replicates. 


\section{Clonogenic assay of cell in vitro}

The clonogenic assay was carried out as previously described [14]. 100-130 cells/well and incubated for $24 \mathrm{~h}$ at $37{ }^{\circ} \mathrm{C}$ with $5 \% \mathrm{CO}_{2}$ to lead attach. The cells were treated with the corresponding $\mathrm{IC}_{50}$ for $24 \mathrm{~h}$ and were cultured for 7-14 additional days. Then, the cultures were stained with $0.5 \%$ crystal violet for $30 \mathrm{~min}$. Colonies containing more than 50 cells (after 10-14 days of incubation) were counted using ImageJ software [15]. Three independent experiments were performed with three technical replicates each one.

\section{Wound and healing assay}

Wound and healing assay was carried out as previously described [16]. $5 \times 10^{4}-6 \times 10^{5}$ cells were seeded and grown overnight to reach $100 \%$ confluency. The monolayer was treated with the corresponding $\mathrm{IC}_{50}$ for $24 \mathrm{~h}$. The cells were migrated into the scratched area and photographed (camera infinity 1-2, Lumenera Corp., CA) every $24 \mathrm{~h}$. The migrated cells were expressed as a mean value per field. Three independent experiments were performed with three technical replicates each one.

\section{Cell morphology and membrane permeability assays}

Cells were seeded in a 96-well plate for $24 \mathrm{~h}$. After attachment, the cells were treated with $T$. peruviana fruit extract using the $\mathrm{IC}_{50}$ concentration for 4, 8, 16 and $24 \mathrm{~h}$. For cell morphology, the cells were observed using an inverted microscope (Olympus IX71). Trypan blue assay was used for the permeability assay (0.4\% trypan blue/per well) [17]. As a negative control, cells were cultivated in the same plate without the plant extract. Each sample was observed under the microscope and photographs were taken immediately after staining. Three independent experiments were performed with three technical replicates.

\section{DNA fragmentation analysis}

DNA fragmentation was carried out as described previously [18]. Cells were grown in the presence or absence of T. peruviana fruit extract using the $\mathrm{IC}_{50}$ concentration for $24 \mathrm{~h}$. Doxorubicin treated cells were used as positive control. Briefly, $5 \times 10^{5}$ cells were lysed in DNA lysis buffer [1 M Tris- $\mathrm{HCl}$ (pH 8.0), 0.5 M EDTA, 100\% Triton $\mathrm{X}-100,2 \% \mathrm{SDS}, 0.2 \mathrm{M} \mathrm{NaCl}$, and then, DNA was extracted. The nucleic acid concentration and purity were measured using a NanoDrop ${ }^{\circ}$ ND-2000 spectrophotometer (Thermo Scientific). Equal amounts of DNA (10 $\mu \mathrm{g} /$ well) were electrophoresed in 1\% agarose gel. DNA fragments were visualized using an UV transilluminator (MutilDoc-it Digital Imaging System UVP). Three independent experiments were performed.
Dual acridine orange/ethidium bromide (AO/EB)

\section{fluorescent staining}

For the AO/EB method, $5 \times 10^{5}$ cells were seeded in a 6-well plate. Cells were treated with $T$. peruviana fruit extract at the corresponding $\mathrm{IC}_{50}$ concentration for $4 \mathrm{~h}$. Then cells were subjected to $\mathrm{AO} / \mathrm{EB}$ staining as described previously [19]. Briefly, cells were tripsinized and re-suspended in cold PBS and AO/EB dye mix $(100 \mu \mathrm{g} /$ $\mathrm{mL} \mathrm{AO}$ and $100 \mu \mathrm{g} / \mathrm{mL}$ EB; Sigma) was added. Stained cell suspensions $(10 \mu \mathrm{L})$ were viewed and counted using a Nikon eclipse TS100 inverted microscope at 40× magnification with excitation filter $480 / 30 \mathrm{~nm}$ and barrier filter $535 / 40 \mathrm{~nm}$. Six fields per sample were examined. The AO/EB staining method was repeated 3 times.

\section{Liquid chromatography - Mass spectrometry analysis}

HRESIMS data were collected and in positive and negative ionization modes using a Thermo QExactive Plus mass spectrometer (ThermoFisher) equipped an electrospray ionization (ESI) source and via an Acquity UPLC system (Waters Corp). The higher-energy collisional dissociation (HCD) cell used a normalized collision energy of $30 \mathrm{eV}$ for all the compounds to obtain MS/MS data. The UPLC separation was performed using an Acquity $\mathrm{BEH} \mathrm{C}_{18}$ column equilibrated at $40{ }^{\circ} \mathrm{C}$ and a flow rate set at $0.3 \mathrm{~mL} / \mathrm{min}$. The mobile phase consisted of $15 \% \mathrm{CH}_{3} \mathrm{CN}-\mathrm{H}_{2} \mathrm{O}(0.1 \%$ formic acid) for $0.5 \mathrm{~min}$, and then a linear gradient from $15 \%$ $\mathrm{CH}_{3} \mathrm{CN}$ to $100 \% \mathrm{CH}_{3} \mathrm{CN}$ over $6 \mathrm{~min}$, and 1 min holding $100 \% \mathrm{CH}_{3} \mathrm{CN}$ before returning to the starting conditions. Samples were dissolved in MS grade methanol and filtered through a $0.2 \mu \mathrm{m}$ Acrodisc (Waters) filter. Tentative metabolite identification was performed by comparison of HRMS data, UV maxima and fragmentation patterns (MS/MS data) with those contained in the Dictionary of Natural Products [20] reference compounds refined for Thevetia plant metabolites.

\section{Data Analysis}

Statistical analysis was performed using GraphPad Prism 7 software. The $p$-value was analyzed in comparison to the untreated samples using Student's $t$-Test or using oneway analysis of variance (ANOVA) followed by a Tukey test for comparison between different treatment groups. Differences were considered statistically significant at $p<0.05$. Results were expressed as mean \pm SEM of data obtained from tripled or quintuplet, independent experiments. Multivariate analysis was performed using the $\mathrm{R}$ 3.2.5 environment. Three biological replicates for each cell line were evaluated, and the variables used were the $\mathrm{IC}_{50}$, the clonogenic assay (CL), the membrane permeability (MP) and the wound-healing assay (WH). A standardized principal component analysis (PCA) was performed with "ade4" package [21], followed by an independent component analysis (ICA) applied to the PCA patterns [22]. 


\section{Results}

Cytotoxic activity of $T$. peruviana fruit methanol extract on human prostate, breast, colorectal, and lung cancer cell lines

In order to assess the cytotoxic effect of the $T$. peruviana methanol extract on breast (HTB-22), colorectal (HTB-38), prostate (HTB-81), and lung (HTB-177) cancer cell lines, a MTT assay was performed. $\mathrm{IC}_{50}$ values indicate the concentration of the extract that inhibits the growth of $50 \%$ of the cell population. The criteria of cytotoxicity established by the U.S. National Cancer Institute (NCI) considers a crude extract as active, moderately active, or inactive, when the $\mathrm{IC}_{50}$ values are lower than $20 \mu \mathrm{g} / \mathrm{mL}$, from 20 to $100 \mu \mathrm{g} / \mathrm{mL}$, or higher than $100 \mu \mathrm{g} / \mathrm{mL}$, respectively [23]. $T$. peruviana methanol fruit extract induced strong cytotoxicity in all four cancer cell lines $(<20 \mu \mathrm{g} / \mathrm{mL})$, but prostate cancer cells showed the lowest $\mathrm{IC}_{50}$ after treatment with $T$. peruviana extract $\left(\mathrm{IC}_{50}, 1.91 \pm 0.76 \mu \mathrm{g} / \mathrm{mL}\right.$; Table 1$)$. In contrast, the methanol extract of $T$. peruviana exhibited moderate activity against Vero cells and it was inactive against fibroblast cell line (Table 1). Accordingly, the $T$. peruviana fruit extract is cytotoxic to human cancer cell lines, but moderately active on Vero cells and inactive on healthy human fibroblast cells.

\section{T. peruviana fruit methanol extract inhibits the} proliferative ability of four human cancer cell lines

The effect of the $T$. peruviana extract on colony forming ability in four cancer cell lines was investigated. Clonogenic assay was carried out to assess the differences in reproductive viability between treated and untreated cells with $T$. peruviana extract. One hundred cancer cells were seeded in the presence or absence of $T$. peruviana extract, and after 10-15 days of incubation, the colonies formed were counted. The number of colonies observed was significantly inhibited by the T. peruviana extract (Fig. 1a). Colony forming ability was reduced by $80 \%$ in the breast and prostate cancer cells, while colorectal and lung cancer cells were reduced by $70 \%$ (Fig. 1b). In contrast, no defect in proliferation ability was observed for normal cell lines (Fig. 1a, b). Positive control (doxorubicin) inhibited the colony forming ability of both cancer and normal cell lines (Additional file 1: Figure S1). These results suggest that the $T$. peruviana fruit extract has strong anti-proliferative activity against different types of cancer cells without displaying alterations on normal cell lines.

\section{T. peruviana fruit extract affects the cell motility of human cancer cell lines}

The effect of the T. peruviana fruit extract on cell motility was researched using a wound-healing assay. Cancer cells were evaluated in the presence or absence of the plant extract, monitoring until the induced wound was completely closed. Untreated cells exhibited complete wound closure at 24, 48, 96, and $144 \mathrm{~h}$ for the human prostate, breast, lung, and colorectal cancer cell lines, respectively. In contrast, all cancer cell lines evaluated showed a dramatic inhibition of wound closure when treated with the $T$. peruviana extract. The wound closure of Vero and fibroblast cells was achieved at $48 \mathrm{~h}$, whether exposed to the fruit extract or not (Additional file 2: Figure S2). As a positive control, doxorubicin was used in wound-healing assay and showed an increase in the wound due to strong detachment of both the human cancer and normal cell lines (Additional file 3: Figure S3). These results indicated that the $T$. peruviana fruit extract inhibited and delayed the migration of four different human cancer cells in vitro.

\section{Morphological changes in four human cancer cell lines exposed to $T$. peruviana extract}

All the human cell lines displayed significant morphological changes when treated with $T$. peruviana fruit extract for $24 \mathrm{~h}$ (Fig. 2). Thus, we checked whether changes in cell morphology occurred during the incubation of the cells with media containing plant extract. Morphological changes of human cancer cells treated with plant extract were monitored up to $24 \mathrm{~h}$. At $8 \mathrm{~h}$ of incubation, some cells were rounded up in the prostate, lung, and breast cancer cells. After $16 \mathrm{~h}$ of treatment, the cells had shrunk and showed disrupted intercellular contacts. In some cases, the cells were bi-nucleated and the majority of the cells were detached from the wells, denoting cell death. These changes were more drastic for the prostate, breast, and lung cancer cell lines than for colorectal cells and the most prominent effect in the latter was membrane blebbing (small protrusions of the membrane). Because cells did not show vacuolation in the cytoplasm, we considered that autophagy is not involved in the mechanism of cell death [24]. To highlight,

Table $1 I_{50}$ values of $T$. peruviana fruit extract on prostate, lung, colorectal and breast cancer cell lines

\begin{tabular}{|c|c|c|c|c|c|}
\hline \multicolumn{6}{|c|}{$\mathrm{IC}_{50}(\mu \mathrm{g} / \mathrm{mL}) \pm \mathrm{SEM}$} \\
\hline \multicolumn{4}{|c|}{ Cancer cell lines } & \multicolumn{2}{|c|}{ Normal cell lines } \\
\hline Prostate & Breast & Colorectal & Lung & Vero & Fibroblast \\
\hline $1.91 \pm 0.76^{a}$ & $5.78 \pm 2.12^{a}$ & $6.30 \pm 4.45^{a}$ & $12.04 \pm 3.43^{a}$ & $57.02 \pm 14.8^{b}$ & $1578 \pm 301^{c}$ \\
\hline
\end{tabular}

Human cancer cell lines were treated with different concentrations of $T$. peruviana fruit extract in 96 -well microcultured plates for 24 h. IC 50 values are expressed as mean \pm standard error of mean (S.E.M) of quintuplicate determinations. Different letters represent statistically significant differences determined by one way ANOVA $(\rho<0.05)$, followed by Tukey's multiple comparison test 


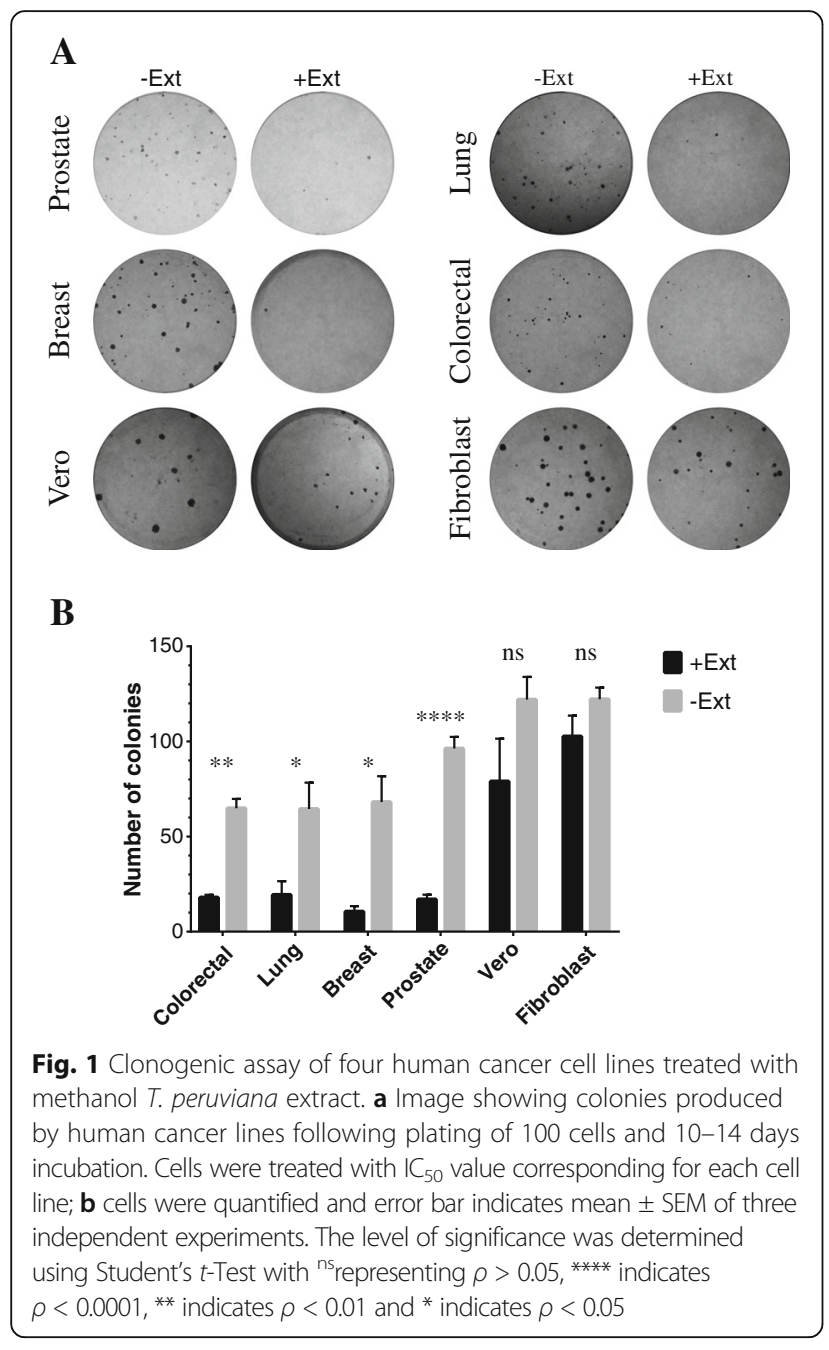

normal cell lines showed no evident morphology alteration during the $24 \mathrm{~h}$ of treatment with $T$. peruviana fruit extract. When control treatment with doxorubicin was applied, cell morphology was altered in both human cancer and normal cells (Additional file 4: Figure S4). These results indicated that after $8 \mathrm{~h}$ of exposure to the T. peruviana extract, the cancer cells presented significant morphological alterations without any observed change in the healthy cell lines.

\section{T. peruviana extract affects the viability of human cancer cells in a time-dependent manner}

To determine whether the viability of the human cancer cells is affected during treatment with $T$. peruviana extract, the trypan blue exclusion test was used. Loss of the integrity of plasma membrane can be verified using polar dyes, such as trypan blue, which is excluded by an intact membrane. We observed that the number of dead cells increased in a time-dependent manner in the presence of the extract plant. The effect of the T. peruviana extract on cell viability of the breast and prostate cancer cells was $50-60 \%$ viability after $8 \mathrm{~h}$ of treatment, whereas the lung and colorectal cancer cells had $80 \%$ viability after $8 \mathrm{~h}$. After $24 \mathrm{~h}$, the lung, prostate, and breast cancer cells showed viability decreased to below 25\% (Fig. 3). Interestingly, the colorectal cancer cells were less sensitive to plant extract showing $70 \%$ of viability after $24 \mathrm{~h}$ treatment. Vero and fibroblast cells showed a small decrement or none at all in viability during the treatment with the T. peruviana fruit extract. This result confirms that $T$. peruviana extract has a cytotoxic effect (at the level of membrane integrity) on different types of cancer cells whereas the normal fibroblast cells were not affected.

\section{Motility and membrane permeability features are mainly affected by $T$. peruviana fruit extract}

Multivariate analysis was performed on the six cell lines (four tumoral and two normal), using as variables to be evaluated: the $\mathrm{IC}_{50}$ value, the clonogenic assay, the wound healing assay, and membrane permeability. PCA was applied to the whole dataset and the first 3 principal components (PC's) accounted for $97.3 \%$ of the observed variability. Assuming that directions with the greatest variance are the most biologically relevant, these leading PC's were selected as those with the major structure or variance, as a de-noising step enhancing ICA results. ICA obtained 3 independent components (IC1, IC2 and IC3) with negative kurtosis $(-1.62,-1.42$ and -0.12 , respectively). The employment of these components, plotting IC1 and IC2, allowed the effective separation of samples into their original groups (Fig. 4). With this, ICA was able to distinguish between the sensitivity of normal (right side) and cancer cells (left side) exposed to T. peruviana extract (with colorectal cancer cell between both populations). The IC1 clearly separates tumor cells from normal cells, mainly due to the effect of the extract on cell motility (wound healing assay) and the membrane permeability, while the IC2 separates samples mainly on the basis of the $\mathrm{IC}_{50}$ observed for each cell line. The anti-proliferative (clonogenic assay) response of the cell lines to the extract is mainly represented by the IC3, which can be observed in the Additional file 5: Figure S5. Overall, this analysis identified that the main features affected by the $T$. peruviana extract were cell motility and membrane permeability and, less significantly, the $\mathrm{IC}_{50}$ and anti-proliferative activity.

\section{T. peruviana fruit extract induces DNA fragmentation in four types of human cancer cells}

The detection of the DNA fragmentation is a common hallmark of cells undergoing late-stage apoptosis [25]. In order to determine if $T$. peruviana fruit extract could induce DNA fragmentation and thus whether apoptosis occurred, human cancer cells exposed to $T$. peruviana treatment were assessed for DNA laddering and visualized 


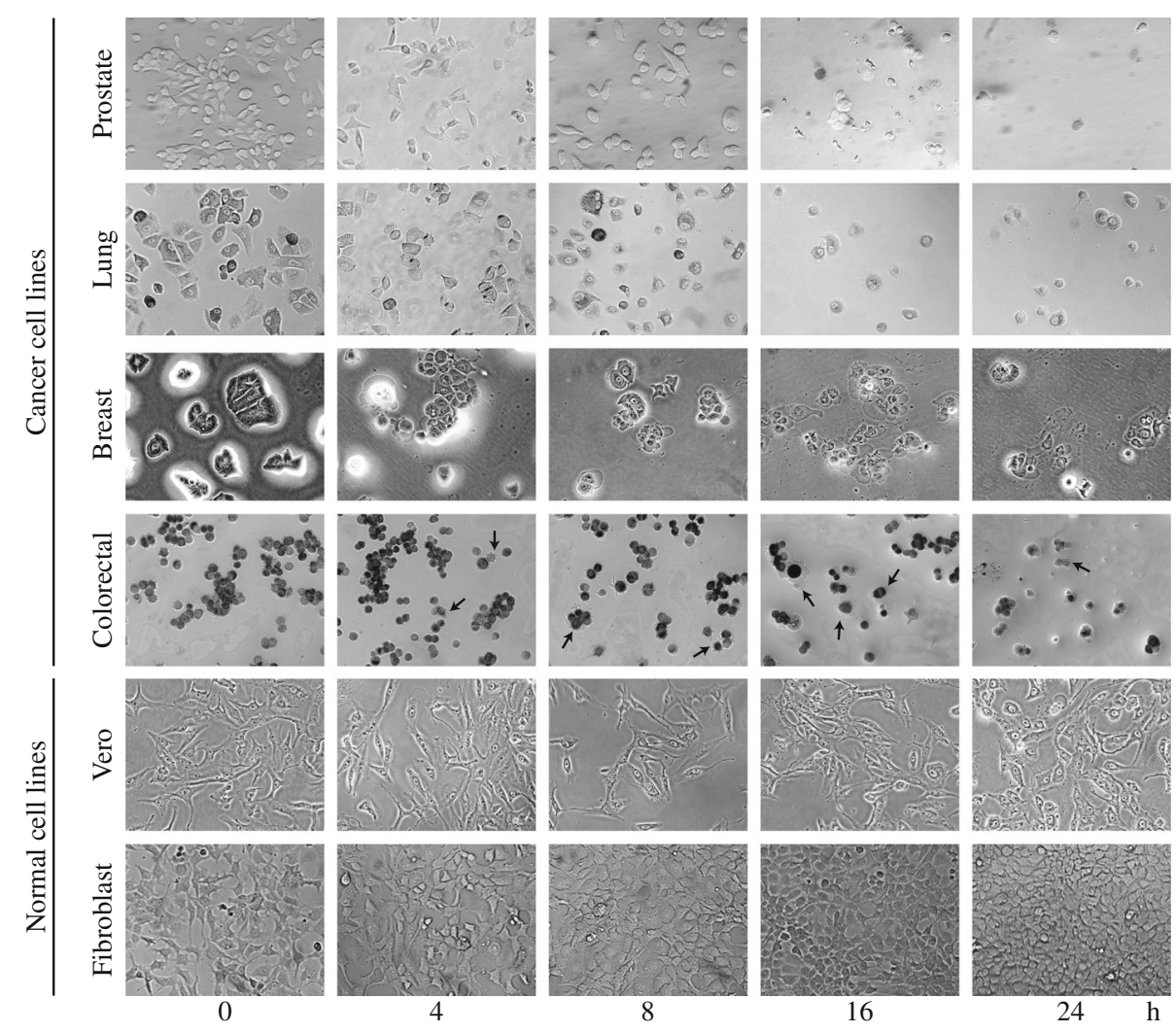

Fig. 2 Morphological changes on four human cancer cell lines during treatment with T. peruviana methanol extract. Human cancer cells were treated at $\mathrm{IC}_{50}$ corresponding value for each cell line and monitored over a period of $24 \mathrm{~h}$. Black arrows indicated blebbing membranes

by agarose gel electrophoresis (Fig 5). It was found that the four human cancer cell lines incubated with $T$. peruviana extract showed apoptotic DNA fragmentation profiles similar to the positive control, doxorubicin, which is known to induces apoptosis [26]. No nucleic acid fragmentation was observed in untreated cells. Normal cell lines showed a lower degree of DNA fragmentation compared with cancer cell lines.

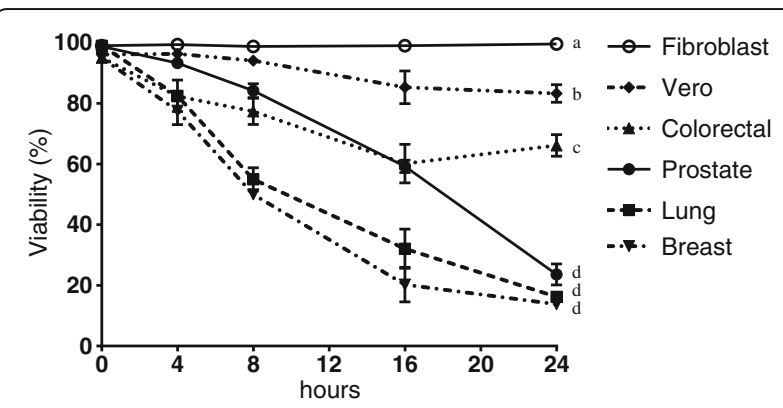

Fig. 3 Viability of four human cancer cells exposed to T. peruviana methanol extract over a period of $24 \mathrm{~h}$. Human cancer cells were treated at $I_{50}$ value corresponding for each cell line. Cell viability was evaluated using the trypan blue exclusion method. Each data point represents values from three independent experiments $(n=3)$. Error bar indicates mean \pm SEM. Different letters represent statistically significant differences determined by one way ANOVA $(\rho<0.05)$

\section{Apoptosis induction by $T$. peruviana fruit extract on human lung and prostate cancer cells}

It was observed that $T$. peruviana extract triggered morphological changes and DNA fragmentation in a timedependent manner that could be related to apoptosis. To determine and quantify cell death, acridine orange/ ethidium bromide (AO/EB) fluorescent staining was used to identify apoptosis-associated changes in the cell membrane. $\mathrm{AO}$ is a membrane-permeable dye that binds to the nucleic acids of viable cells. EB is an impermeable dye, but readily penetrates the membrane of nonviable cells and binds to DNA. When AO/EB are used simultaneously, viable cells fluoresce green and nonviable cells fluoresce red under fluorescence microscopy. Lung and prostate cells were labeled by AO/EB after $4 \mathrm{~h}$ of treatment with the $T$. peruviana extract, and dual staining was examined under a fluorescent microscope. Early and late-stage apoptotic cells, marked by crescent-shaped or granular yellow-green $\mathrm{AO}$ nuclear staining (as indicated by condensed or fragmented chromatin) were detected in the treated group (with T. peruviana extract) and the positive control (doxorubicin treated) (Fig. 6a). Also, dead cells from direct necrosis were detected, having an orange nucleus. No significant apoptosis was detected in the negative control group (untreated cells), which 


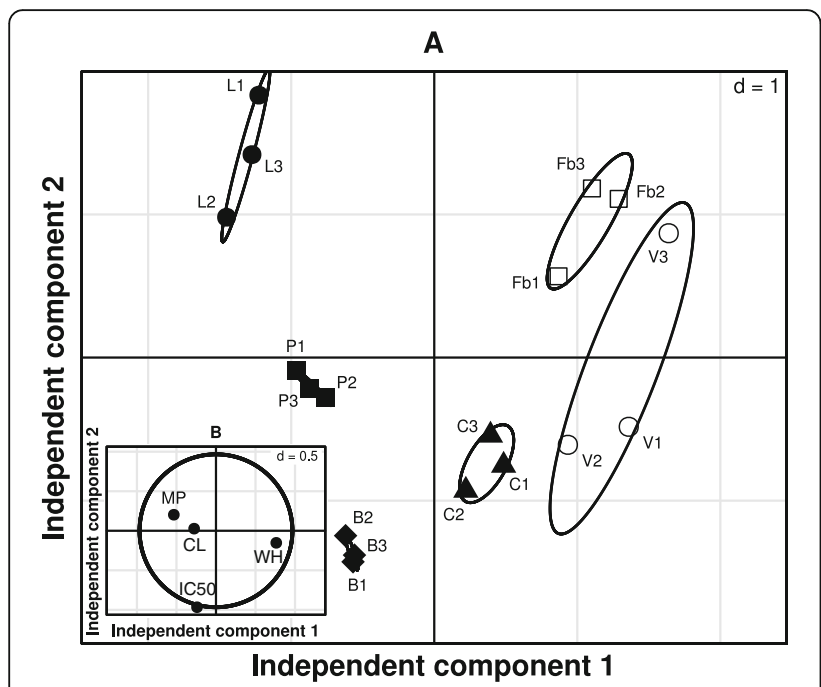

Fig. 4 Classification of normal and cancer cell lines exposed to $T$. peruviana fruit methanolic extract according to independent component analysis (ICA). The distribution of the cell lines (panel A, projections with 95\% confidence ellipses) and variables (panel B, projection of variable loadings, with maximum loading indicated by a circle) is shown in the space spanned by the two leading independent components. The clear unsupervised discrimination among the six cell lines reflects the greater effect of $T$. peruviana extract on tumor cell lines (lung cells, L, $\bullet$, prostate cells, $\mathrm{P}, \mathbf{\square}$, breast cells, B, colorectal cells, C, $\mathbf{\Delta}$ ), while normal cells are less affected (fibroblast cells, Fb, $\square$, Vero cells, V, o). The independent component 1 is clearly separating cancer cells from normal cells, mainly due to the effect of the extract on the motility $(\mathrm{WH})$ and membrane permeability (MP), while the independent component 2 is separating samples mainly by the $\mathrm{IC}_{50}$ value observed for each cell line

showed a normal green nucleus. Quantification of the live, apoptotic, and necrotic cell populations in the control and treated human prostate and lung cancer cells indicated that after $4 \mathrm{~h}$ of treatment, the prostate and lung cancer cells increased the early apoptosis stage by $40.65 \%$ and $41.51 \%$, respectively (Fig. 6b). Thus, in accordance with our DNA fragmentation results, the $T$. peruviana fruit extract triggers apoptosis.

\section{Metabolic profiling of $T$. peruviana fractions by LC-MS analysis}

Methanol extract of $T$. peruviana fruit was subjected to flash chromatography and six fractions were obtained. Because prostate cancer cells showed the lowest $\mathrm{IC}_{50}$ to T. peruviana crude extract compared to lung, breast, and colorectal cancer cells, every single fraction was analyzed on the prostate cancer cell line by MTT assay, fractions four and five being the most significantly cytotoxic (Table 2). Those fractions were analyzed using UPLC-PDA coupled with a HRESIMS-MS/MS spectrometer. Each peak contained in the fractions was dereplicated for their UV profile, HRMS data in both positive and negative modes, and for its MS/MS fragmentation pattern against a refined subset of plant metabolites of Thevetia species contained in the Dictionary of Natural Products (286,310 compounds contained in the database). The results showed that these fractions contained the polyketide thevetiaflavone and the cardiac glycosides: peruvosidic acid, peruvoside, thevefoline, solanoside, neriifoside and neriifolin.

\section{Discussion}

T. peruviana belongs to the Apocynaceae family, a plant which is native to central and southern Mexico, as well as Central America. It is a medicinal plant used to treat different diseases, including cancer [27]. The leaves of yellow oleander had previously been studied and shown to possess antimicrobial, antifungal, antidiarrheal, insecticide, molluscacide, and rodenticide activity [8, 28-30]. However, scientific evidence to demonstrate mode of action, targets and agents responsible for the bioactivity in the fruit is still needed. The purpose of the present study was to find out the cytotoxic and anti-proliferative activity of methanol extracted fruit of $T$. peruviana on different types of human cancer cell lines.

Our experiments in vitro showed that $T$. peruviana fruit extract exhibited strong cytotoxicity against four cancer cell lines. Among the cell lines examined, lung cells showed higher $\mathrm{IC}_{50}$ value $(12.04 \mu \mathrm{g} / \mathrm{mL})$ than

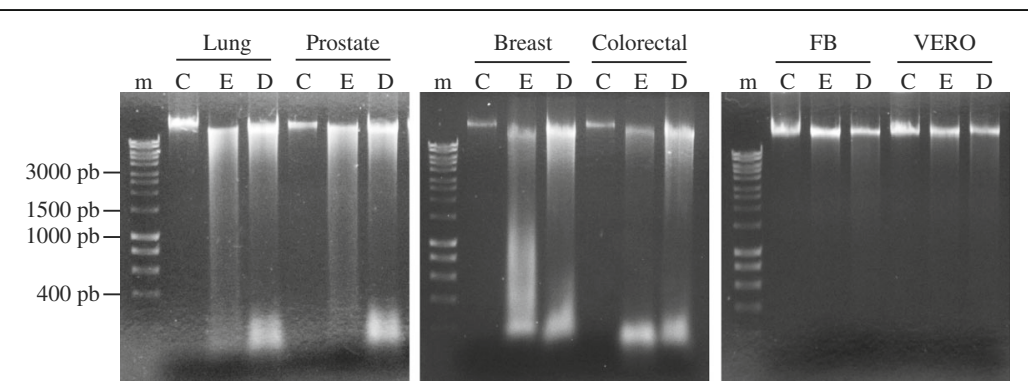

Fig. 5 DNA fragmentation of human cancer cell lines treated with T. peruviana methanol extract. Lung, prostate, breast and colorectal cancer cell lines were treated with the corresponding $\mathrm{IC}_{50}$ value for each cell line during a $24 \mathrm{~h}$ period; $\mathrm{m}$, molecular-weight marker; $\mathrm{C}$, untreated control; $\mathrm{E}$, cancer cell line treated with $T$. peruviana methanol extract at its corresponding $I C_{50}$ value and, $D$, cancer cell line treated with doxorubicin $(10 \mu \mathrm{g} /$ $\mathrm{mL}$ ). Representative result from three independent experiments is shown 


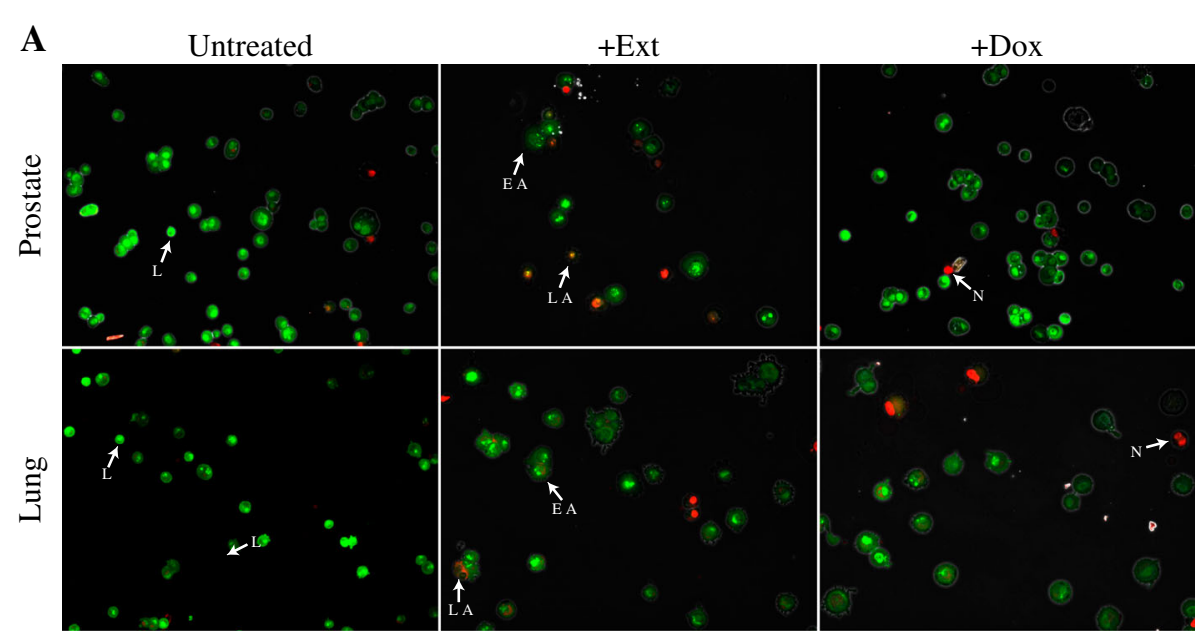

B

Prostate
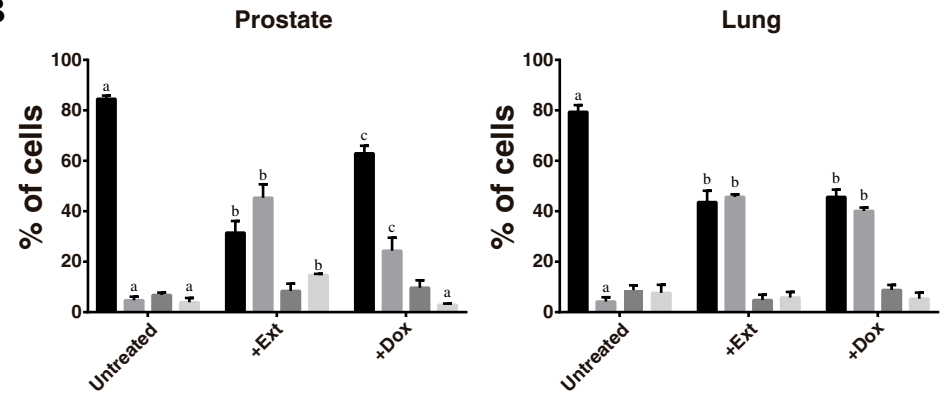

Live

Early apoptosis

Late apoptosis

Necrotic

Fig. $6 \mathrm{AO} / \mathrm{EB}$ double stain of human cancer cell lines after a treatment with $T$. peruviana methanol extract. a. Prostate and lung cells were treated with $I C_{50}$ of $T$. peruviana methanol extract. Images represent the control (untreated cells), treated cells and, cell treated with doxorubicin ( $10 \mu \mathrm{g} / \mathrm{mL}$ ) as positive control. Cells were stained with acridine orange and ethidium bromide (AO/EB) after 4 h of treatment. White arrows indicate live (L), early apoptotic (EA), late apoptotic (LA) or necrotic (N) cells. b. Error bar indicates mean \pm SEM of three independent experiments. +Ext and +Dox, both indicate cells treated with extract or doxorubicin. Different letters represent statistically significant differences determined by one way ANOVA $(\rho<0.05)$ between bars with same color by cell line. Non-letter bars have no statistical difference

prostate $(1.91 \mu \mathrm{g} / \mathrm{mL})$, breast $(5.78 \mu \mathrm{g} / \mathrm{mL})$, and colorectal $(6.30 \mu \mathrm{g} / \mathrm{mL})$ cells. Such variation among the cell lines might be attributed in part to the fact that cancer cells possess differences in their genetic make up, morphology and doubling time, resulting in differential susceptibility to the same cytotoxic agent [31]. Our results, together with previously reported toxic activity, suggest that $T$.

Table 2 Cell viability of the fractions of T. peruviana fruit extract on prostate cancer cell line (HTB-81)

\begin{tabular}{ll}
\hline Fraction & \% Viability \\
\hline 1 & $116 \pm 3.7^{\mathrm{a}}$ \\
2 & $121 \pm 5^{\mathrm{a}}$ \\
3 & $103 \pm 4^{\mathrm{a}}$ \\
4 & $3.71 \pm 3.4^{\mathrm{b}}$ \\
5 & $1.24 \pm 1.9^{\mathrm{b}}$ \\
6 & $62 \pm 3^{\mathrm{c}}$
\end{tabular}

The fractions were obtained by flash chromatography. Viability was determined by MTT assay, values being expressed as mean \pm SEM of triplicate determinations. Different letters represent statistically significant differences determined by one way ANOVA $(\rho<0.05)$, followed by Tukey's multiple comparison test peruviana fruit methanol extract has an antiproliferative potential.

Cancer is a complex disease characterized by proliferation of highly resistant cells to death. An increased rate of cellular proliferation is frequent, due to the fact that most cancer cells divide more often than normal cells. The goal of targeting cell proliferation is to arrest the cell cycle or induce cancer cell death using cytotoxic compounds. We show here, that $T$. peruviana fruit extract significantly reduced the cell viability and the ability of cells to form colonies in four different human cancer cell lines. The clonogenic assay has been used to detect cells that have retained their capacity to produce a large number of progeny after radiation and chemotherapy treatments [32]. It also correlates tumorigenicity analysis in vivo and predicts the clinical response toward several agents in breast cancer patients [33]. Hence, our results in clonogenic assay suggest that $T$. peruviana fruit extract has potential anticancer activity, limiting proliferation of cancer cells after treatment. Notably, normal cells (vero and fibroblast) treated with 
T. peruviana extract did not show any observable effect in clonogenic assay.

Migration is a critical step in initial progression of cancer that facilitates metastasis. Wound and healing assay is a classic and common method used for discovery and validation of molecules that affect cell migration $[16,34]$ and metastasis [35]. The methanolic $T$. peruviana fruit extract inhibited and delayed the cell migration of cancer cells, but not among normal cells. These results open the door to further studies that could confirm if the cytotoxic activity of $T$. peruviana fruit extract alters the regulation of the actin cytoskeleton, induces morphological changes and leads to detachment of cells, culminating in cell death. Moreover, motility and membrane permeability features were mainly affected by $T$. peruviana fruit extract, according with the multivariate analysis performed on the six cell lines and the four variables evaluated, suggesting a potential antimetastatic activity in the $T$. peruviana fruit extract.

One crucial and desirable mechanism by which chemotherapeutics destroy tumor cells is by inducing apoptosis. Cells undergoing apoptosis show morphological and biochemical modifications including chromatin segregation, nuclear condensation, DNA fragmentation, partition of the membrane, and vesicles formation [36, 37]. The late-stage of apoptosis can be visualized by standard agarose gel electrophoresis as a ladder pattern due to DNA cleavage [38], while both (the early and late stages of apoptosis) can be determined by AO/EB fluorescent staining. Cerbera manghas, a plant belonging to the Apocynaceae family, contains a cardiac glycoside (neriifolin), which induced DNA fragmentation on hepatocellular carcinoma $48 \mathrm{~h}$ after treatment [39]. Here, crude extract from T. peruviana fruit showed death induction on cancer cell lines through early apoptosis mechanisms (AO/EB fluorescent staining) $4 \mathrm{~h}$ after treatment and late-stage apoptosis (DNA laddering assay) after $24 \mathrm{~h}$ of treatment. This result indicates that $T$. peruviana could have a higher level of apoptotic activity than other members of the Apocynaceae family. In addition, it will be important to determine whether the apoptotic activity is located in the compounds present in the flesh or seeds.

Mass spectrometry analysis of active fractions from $T$. peruviana fruit methanol extract indicated that one flavonoid and cardiac glycosides are secondary metabolites present in the fruit plant. Flavonoids, such as curcumin, quercentin and genistein, are known to have cell linespecific anti-proliferative and apoptosis inducing activity [40-42]. It has been postulated that flavonoids possess anticancer properties manifested through several mechanisms, including decrease of reactive oxygen species, inhibition of DNA topoisomerase and downward regulation pathway of nuclear transcription factors [43-46]. Further experiments are required to determine the cytotoxic effect of thevetiaflavone and individual cardiac glycosides present in the methanolic fruit extract of $T$. peruviana on human cancer cell lines. Recent investigations of seeds from $T$. peruviana resulted in the isolation of cardiac glycosides that had inhibitory effects against human gastric and pancreatic cancer cell lines [11]. Cardiac glycosides are the most researched secondary metabolites in $T$. peruviana due to the fact they can heal heart pathologies [47], but are also being studied for their cytotoxic and/or apoptotic activities against myeloid leukemia (peruvoside) [48] and hepatocellular carcinoma (neriifolin) [39]. Thevetin and peruvoside are cardiac glycosides which are clinically important constituents due to be used in treatment of arrhythmias [49]. One hundred nine cardenolides have been isolated and identified from members of the Apocynaceae family, and about a quarter of them are reported to have anticancer activity. Cardenolides are well known as the substrates of $\mathrm{Na}+/ \mathrm{K}+-$ ATPase, which is an enzyme that regulate various cell survival and death signal pathways [6] and its relative distribution and expression are distinct in cancer cells compared with normal ones, indicating that they could serve as a novel target with great potential. This could be the reason that multivariate analysis showed an adequate separation between normal and cancer cells, revealing significant differences in their sensitivity to the toxic compounds in the $T$. peruviana fruit methanolic extract, mainly due to the effect of the extract on the motility and membrane permeability on human prostate, breast, colorectal and lung cancer cell lines. The cytotoxic activity of crude extract from $T$. peruviana fruit could be attributed to their phytochemical components such as thevetin A, thevetin B, peruvoside, thevenerin, and cerberin, which are toxins [50], and also to the cardiac glycosides found in active fractions reported in this study (thevefoline, solanoside, neriifoside, peruvoside and neriifolin). Finally, the isolation of the active principles of the methanolic extract of $T$. peruviana fruit is currently being undertaken to investigate their cytotoxic, molecular and genetic action mechanisms, which could provide meaningful perspectives for biomedical and biotechnological research.

\section{Conclusions}

The current study presents evidence that the methanol extract of $T$. peruviana fruit inhibits cell proliferation, has a time-dependent cytotoxic activity and induces apoptosis of human cancer cell lines, but has minimal or less pronounced effects on normal cells. The fruit extract displayed anticancer properties mainly through mechanisms that included membrane permeability, motility and DNA fragmentation. Maximum cytotoxic activity was observed in a fraction that contained one flavonoid and cardiac glycosides. Chemical analyses of the active fractions are currently in progress to perform a better evaluation of 
their biological significance. Additionally, further "in vivo" research is essential to show the full potential for the use of T. peruviana fruit extract in cancer therapy. In conclusion, these findings shows the importance of $T$. peruviana fruit as a source of bioactive compounds with anticancer potential.

\section{Additional files}

Additional file 1: Figure S1. Clonogenic assay of four human cancer cell lines treated with doxorubicin. Image showing colonies produced by human cancer lines and normal cell lines, following plating of 100 cells and 10-14 days incubation. Cells were treated with doxorubicin at $10 \mu \mathrm{g} / \mathrm{mL}$. (PDF $1719 \mathrm{~kb}$ )

Additional file 2: Figure S2. Wound and healing closure activity of four human cancer cell lines treated with methanol T. peruviana extract. Representative photographs of wounded cancer cells monolayer after $24 \mathrm{~h}$ of treatment with methanol $T$. peruviana fruit extract at $I C_{50}$ value corresponding to each cell line. Vero and fibroblast cells were used as normal cell lines. A typical result from three independent experiments is shown. (PDF $2.74 \mathrm{mb}$ )

Additional file 3: Figure S3. Wound and healing closure activity of four human cancer cell lines treated with doxorubicin. Representative photographs of wounded cancer cells monolayer after $24 \mathrm{~h}$ of treatment with doxorubicin at $10 \mu \mathrm{g} / \mathrm{mL}$. The result from three independent experiments is shown. (PDF $2.62 \mathrm{mb}$ )

Additional file 4: Figure S4. Morphological changes on four human cancer cell lines during treatment with doxorubicin. Human cancer cells were treated with doxorubicin at $10 \mu \mathrm{g} / \mathrm{mL}$ and monitored over a $24 \mathrm{~h}$ period. (PDF $1.88 \mathrm{mb}$ )

Additional file 5: Figure S5. Classification of normal and cancer cell lines exposed to $T$. peruviana fruit methanolic extract according to independent component analysis (ICA). The distribution of the cell lines (panel A, projections with 95\% confidence ellipses) and variables (panel B, projection of variable loadings with maximum loading indicated by a circle) is shown in the space spanned by the independent components 1 and 3. The clear unsupervised discrimination among the six cell lines reflects the greater effect of $T$. peruviana extract on tumor cell lines (lung cells, L, ?, prostate cells, P, i, breast cells, B, ?, colorectal cells, C, ?), while normal cells are affected less (fibroblast cells, Fb, ?, Vero cells, $V$, ?). The independent component 1 is clearly separating cancer cells from normal cells, mainly due to the effect of the extract on the motility $(\mathrm{WH})$ and membrane permeability (MP), while the independent component 3 is separating samples mainly by the anti-proliferative (clonogenic assay, CL) observed for each cell line. (PDF $1121 \mathrm{~kb}$ )

\section{Abbreviations}

AO: Acridine orange; ATCC: American Type Culture Collection; DMEM: Dulbecco's Modified Eagle's medium; DMSO: Dimethyl sulfoxide; EB: Ethidium bromide: IC: Independent component; $I_{50}$. Half maximal inhibitory concentration; ICA: Independent component analysis; MTT: 3-(4,5-dimethylthiazol-2-yl)-2,5diphenyltetrazolium bromide; PBS: Phosphate buffer saline; PC: Principal component; PCA: Principal component analysis; RPMl: Roswell Park Memorial Institute medium

\section{Acknowledgements}

We are grateful to MD Nancy B. Gordon (MD Anderson Cancer Center), for kindly providing training in tissue culture techniques, as well as Dr. Mariana Elizondo Zertuche and Álvaro Colín Oviedo for their support with the fluorescence microscope (CONACYT-INFRA 2015-251142) from Departamento de Microbiología, Facultad de Medicina, UANL. MF thank to CONACyT for the grant INFRA 252226. We thank Yesenia Cristal García Silva for her excellent technical support and express appreciation to Dr. Angel Andrade and Dr. Greoffrey Cordell for their critical examination of the manuscript.

\section{Funding}

This research project was supported by two grants from The Program for Scientific and Technological Research (PAICyT-UANL no. CN373-15) and The National Council for Science and Technology (CONACyT, no. 239695). ASR was supported through a postgraduate scholarship (code 388785) and FTC was supported through a postdoctoral grant (code 173833) from CONACyT.

Availability of data and materials

All data and materials are contained and described in the manuscript.

\section{Authors' contributions}

ARS and FTC carried out cytotoxic activity, clonogenic, scratch motility, morphology and permeability assay, AO/EB staining, and then analyzed the data of HTB-22, HTB-38, HTB-81 and HTB-177 cells. ARG and LJGW performed cytotoxic activity, clonogenic assay, and scratch motility of CL-116 and CCL-81 cells. AGA performs the multivariate analysis. FTC and STZ drafted the manuscript. MF performed the fractionation and LC-HRMS analysis of $T$. peruviana extract and fractions. HAA conceived and designed the experiments and approval of the final draft. All authors have read and approved the final manuscript.

\section{Competing Interests}

The authors declare that they have no competing interests.

\section{Consent for publication}

Not applicable.

Ethics approval and consent to participate

Not applicable.

\section{Publisher's Note}

Springer Nature remains neutral with regard to jurisdictional claims in published maps and institutional affiliations.

\section{Author details}

${ }^{1}$ Instituto de Biotecnología, Facultad de Ciencias Biológicas, Universidad Autónoma de Nuevo León, Avenida Universidad S/N, Ciudad Universitaria, CP 66455 San Nicolás de los Garza, NL, Mexico. ²Facultad de Química, Departamento de Farmacia, Universidad Nacional Autónoma de México, CP 04510 Ciudad de México, Mexico.

Received: 24 December 2016 Accepted: 5 April 2017

Published online: 02 May 2017

\section{References}

1. World wide cancer statistics. Cancer Research UK. http://www. cancerresearchuk.org/health-professional/cancer-statistics/worldwide-cancer. Accessed 24 May 2017.

2. Deep G, Agarwal R. Antimetastatic efficacy of silibinin: molecular mechanisms and therapeutic potential against cancer. Cancer Metastasis Rev. 2010;29:447-63.

3. Liao RG, Watanabe $H$, Meyerson M, Hammerman PS. Targeted therapy for squamous cell lung cancer. Lung Cancer Manag. 2012;1:293-300.

4. Zia-Ul-Haq M, Riaz M, Saad B. Anthocyanins and Human Health: Biomolecular and therapeutic aspects, 1 ed. Switzerland: Springer International Publishing; 2016.

5. Kinghorn AD, EJ DEB, Lucas DM, Rakotondraibe HL, Orjala J, Soejarto DD, Oberlies NH, Pearce CJ, Wani MC, Stockwell BR et al. Discovery of Anticancer Agents of Diverse Natural Origin. Anticancer Res 2016;36:5623-5637.

6. Wen S, Chen Y, Lu Y, Wang Y, Ding L, Jiang M. Cardenolides from the Apocynaceae family and their anticancer activity. Fitoterapia. 2016;112:74-84.

7. Alonso-Castro AJ, Villarreal ML, Salazar-Olivo LA, Gomez-Sanchez M, Dominguez F, Garcia-Carranca A. Mexican medicinal plants used for cancer treatment: pharmacological, phytochemical and ethnobotanical studies. J Ethnopharmacol. 2011;133:945-72.

8. Oji O, Okafor QE. Toxicological studies on stem bark, leaf and seed kernel of yellow oleander (Thevetia peruviana). Phytother Res. 2000;14:133-5.

9. Langford SD, Boor PJ. Oleander toxicity: an examination of human and animal toxic exposures. Toxicology. 1996;109:1-13.

10. Bandara V, Weinstein SA, White J, Eddleston M. A review of the natural history, toxinology, diagnosis and clinical management of Nerium oleander 
(common oleander) and Thevetia peruviana (yellow oleander) poisoning Toxicon. 2010;56:273-81.

11. Tian DM, Cheng HY, Jiang MM, Shen WZ, Tang JS, Yao XS. Cardiac Glycosides from the Seeds of Thevetia peruviana. J Nat Prod. 2016;79:38-50.

12. van Meerloo J, Kaspers GJ, Cloos J. Cell sensitivity assays: the MTT assay. Methods Mol Biol. 2011;731:237-45.

13. Eskandani M, Hamishehkar H. Ezzati Nazhad Dolatabadi J. Cytotoxicity and DNA damage properties of tert-butylhydroquinone (TBHQ) food additive. Food Chem. 2014;153:315-20

14. Rafehi H, Orlowski C, Georgiadis GT, Ververis K, El-Osta A, Karagiannis TC. Clonogenic assay: adherent cells. J Vis Exp. 2011;

15. Collins TJ. ImageJ for microscopy. BioTechniques. 2007:43:25-30.

16. Liang CC, Park AY, Guan JL. In vitro scratch assay: a convenient and inexpensive method for analysis of cell migration in vitro. Nat Protoc. 2007;2:329-33.

17. Strober W. Trypan Blue Exclusion Test of Cell Viability. Curr Protoc Immunol. 2015;111:A3.B.1-3.

18. Lin J, Dong HF, Oppenheim JJ, Howard OM. Effects of astragali radix on the growth of different cancer cell lines. World J Gastroenterol. 2003;9:670-3.

19. Cohen JJ. Apoptosis. Immunol Today. 1993;14:126-30.

20. Dictionary of Natural Products. Version 25.2. http://dnp.chemnetbase.com/. Accessed 24 May 2017.

21. Dray S, Dufour AB. The ade4 package: implementing the duality diagram for ecologists. J Stat Soft. 2007;22:1-20.

22. Marchini JL, Heaton C, Ripley BD. fastlCA: FastlCA Algorithms to perform ICA and Projection Pursuit. R project. 2013. https://CRAN.R-project.org/package= fastlCA. Accessed 24 May 2017.

23. Skehan P, Storeng R, Scudiero D, Monks A, McMahon J, Vistica D, Warren JT, Bokesch H, Kenney S, Boyd MR. New colorimetric cytotoxicity assay for anticancer-drug screening. J Natl Cancer Inst. 1990;82:1107-12.

24. Wasik AM, Almestrand S, Wang X, Hultenby K, Dackland AL, Andersson P. Kimby E, Christensson B, Sander B. WIN55,212-2 induces cytoplasmic vacuolation in apoptosis-resistant MCL cells. Cell Death Dis. 2011;2:e225.

25. Elmore S. Apoptosis: a review of programmed cell death. Toxicol Pathol. 2007:35:495-516.

26. Tacar O, Sriamornsak P, Dass CR. Doxorubicin: an update on anticancer molecular action, toxicity and novel drug delivery systems. J Pharm Pharmacol. 2013;65:157-70

27. Martinez M. Las plantas medicinales de Mexico, vol. 1. Librería y Ediciones Botas: Mexico; 2004

28. Hassan MM, Saha AK, Khan SA, Islam A, Mahabub-Uz-Zaman M, Ahmed SS. Studies on the antidiarrhoeal, antimicrobial and cytotoxic activities of ethanol-extracted leaves of yellow oleander (Thevetia peruviana). Open Vet J. 2011;1:28-31.

29. Gata-Goncalves L, Nogueira JM, Matos O. Bruno de Sousa R. Photoactive extracts from Thevetia peruviana with antifungal properties against Cladosporium cucumerinum. J Photochem Photobiol B. 2003;70:51-4.

30. Obasi IO, Nwachukwu N. Gestational iron deficiency and the related anaemia in northern zone of Ebonyi State. Pak J Biol Sci. 2013;16:1159-65.

31. Hanahan D, Weinberg RA. Hallmarks of cancer: the next generation. Cell. 2011;144:646-74.

32. Franken NA, Rodermond HM, Stap J, Haveman J, van Bree C. Clonogenic assay of cells in vitro. Nat Protoc. 2006;1:2315-9.

33. Jones SE, Dean JC, Young LA, Salmon SE. The human tumor clonogenic assay in human breast cancer. J Clin Oncol. 1985;3:92-7.

34. Yarrow JC, Perlman ZE, Westwood NJ, Mitchison TJ. A high-throughput cell migration assay using scratch wound healing, a comparison of image-based readout methods. BMC Biotechnol. 2004;4:21.

35. Gulhati P, Bowen KA, Liu J, Stevens PD, Rychahou PG, Chen M, Lee EY, Weiss HL, O'Connor KL, Gao T, et al. MTORC1 and mTORC2 regulate EMT, motility, and metastasis of colorectal cancer via RhoA and Rac1 signaling pathways. Cancer Res. 2011;71:3246-56.

36. Fisher DE. Apoptosis in cancer therapy: crossing the threshold. Cell. 1994;78:539-42.

37. Yi JM, Kim MS, Lee EH, Wi DH, Lee JK, Cho KH, Hong SH, Kim HM. Induction of apoptosis by Paljin-Hangahmdan on human leukemia cells. J Ethnopharmacol. 2003;88:79-83.

38. Rahbar Saadat Y, Saeidi N, Zununi Vahed S, Barzegari A, Barar J. An update to DNA ladder assay for apoptosis detection. Bioimpacts. 2015:5:25-8.
39. Zhao Q, Guo Y, Feng B, Li L, Huang C, Jiao B. Neriifolin from seeds of Cerbera manghas $\mathrm{L}$. induces cell cycle arrest and apoptosis in human hepatocellular carcinoma HepG2 cells. Fitoterapia. 2011;82:735-41.

40. Srivastava V, Negi AS, Kumar JK, Gupta MM, SP. K. Plant-based anticancer molecules: a chemical and biological profile of some important leads. Bioorg Med Chem. 2005;13:5892-908.

41. Boreddy SR, Srivastava SK. Pancreatic cancer chemoprevention by phytochemicals. Cancer Lett. 2013;334:86-94.

42. Vijayababu MR, Arunkumar A, Kanagaraj P, Venkataraman P, Krishnamoorthy $G$, Arunakaran J. Quercetin downregulates matrix metalloproteinases 2 and 9 proteins expression in prostate cancer cells (PC-3). Mol Cell Biochem. 2006;287:109-16.

43. Chahar MK, Sharma N, Dobhal MP, Joshi YC. Flavonoids: A versatile source of anticancer drugs. Pharmacogn Rev. 2011;5:1-12.

44. Lee WR, Shen SC, Lin HY, Hou WC, Yang LL, Chen YC. Wogonin and fisetin induce apoptosis in human promyeloleukemic cells, accompanied by a decrease of reactive oxygen species, and activation of caspase 3 and $\mathrm{Ca}(2+)$ dependent endonuclease. Biochem Pharmacol. 2002;63:225-36.

45. Wang IK, Lin-Shiau SY, Lin JK. Induction of apoptosis by apigenin and related flavonoids through cytochrome c release and activation of caspase-9 and caspase-3 in leukaemia HL-60 cells. Eur J Cancer. 1999;35:1517-25.

46. Wenzel $\mathrm{U}$, Kuntz $\mathrm{S}$, Brendel MD, Daniel $\mathrm{H}$. Dietary flavone is a potent apoptosis inducer in human colon carcinoma cells. Cancer Res. 2000;60:3823-31.

47. Josephs RD, Daireaux A, Westwood S, Wielgosz RI. Simultaneous determination of various cardiac glycosides by liquid chromatographyhybrid mass spectrometry for the purity assessment of the therapeutic monitored drug digoxin. J Chromatogr A. 2010;1217:4535-43.

48. Feng Q, Leong WS, Liu L, Chan WI. Peruvoside, a Cardiac Glycoside. Induces Primitive Myeloid Leukemia Cell Death Molecules. 2016;21:534.

49. Misra MK, Sarwat M, Bhakuni P, Tuteja R, Tuteja N. Oxidative stress and ischemic myocardial syndromes. Med Sci Monit. 2009;15:209-19.

50. Nesy EA, Mathew L. Detection and Quantification of Cardiotonic Drug Peruvoside Using HPTLC from Thevetia neriifolia, Juss Seed Extracts. Int J Pharm Sci Invent. 2014;3:11-6.

\section{Submit your next manuscript to BioMed Central and we will help you at every step:}

- We accept pre-submission inquiries

- Our selector tool helps you to find the most relevant journal

- We provide round the clock customer support

- Convenient online submission

- Thorough peer review

- Inclusion in PubMed and all major indexing services

- Maximum visibility for your research

Submit your manuscript at www.biomedcentral.com/submit
Biomed Central 